\title{
PENINGKATAN SIKAP ILMIAH DAN HASIL BELAJAR SISWA DENGAN MODEL PROBLEM BASED LEARNING
}

\author{
Luthfy Aprilianti $^{*}$, Sri Irawati ${ }^{1}$, Kasrina ${ }^{1}$ \\ ${ }^{1}$ Program Studi Pendidikan Biologi, Fakultas Keguruan dan Ilmu Pendidikan, Universitas Bengkulu \\ Email: luthfyaprilianti2828@gmail.com
}

\begin{abstract}
Abstrak
Penelitian ini bertujuan untuk mendeskripsikan aktivitas guru serta meningkatkan sikap ilmiah dan hasil belajar dengan menerapkan model problem based learning pada materi sistem pencemaran lingkungan di kelas VII $\mathrm{B}$ SMPN 11 Kota Bengkulu. Jenis penelitian adalah penelitian tindakan kelas yang dilakukan dalam dua siklus. Setiap siklus terdiri atas empat tahap yaitu perencanaan, pelaksanaan, observasi dan refleksi. Subjek penelitian ini adalah guru dan siswa kelas VII ${ }_{B}$ SMPN 11 Kota Bengkulu tahun ajaran 2016/2017. Variabel penelitian ini adalah model problem based learning, sikap ilmiah, dan hasil belajar. Instrumen penelitian berupa lembar observasi untuk mengetahui aktivitas guru dan sikap ilmiah, sedangkan lembar tes digunakan untuk mengetahui hasil belajar. Hasil analisis data observasi aktivitas guru siklus I diperoleh skor rata-rata 24 (baik), dan di siklus II 28 (baik). Hasil analisis data observasi sikap ilmiah siswa siklus I diperoleh skor rata-rata 17,71 (cukup), siklus II menjadi 20,74 (baik). Pada hasil belajar kompetensi pengetahuan siklus I mendapatkan persentase $66,66 \%$, siklus II menjadi $84,85 \%$, pada hasil belajar kompetensi sikap siklus I mendapatkan persentase $69,69 \%$, siklus II menjadi $100 \%$, pada hasil belajar kompetensi keterampilan siklus I mendapatkan persentase $81,81 \%$, siklus II menjadi $100 \%$. Disimpulkan bahwa model problem based learning dapat meningkatkan sikap ilmiah dan hasil belajar siswa kelas VII ${ }_{B}$ SMPN 11Kota Bengkulu.
\end{abstract}

Kata kunci: Problem Based Learning, Sikap IImiah

\begin{abstract}
This study aimed to describe the teacher activity and improve scientific attitude and learning outcomes by applying Problem Based Learning model on environmental pollution topic in class $\mathrm{VII}_{B}$ SMPN 11 Kota Bengkulu. This type of research was Classroom Action Research with descriptive method. This study consists of 2 cycles, each cycle consists of four phases: planning, action, observation and reflection. The subjects were biology teacher and students of class $\mathrm{VII}_{B}$ SMPN 11 Kota Bengkulu school year 2016/2017. The variables of this research were Problem Based Learning model, scientific attitude, and learning outcomes. The research instrument was an observation sheet to determined teacher activity and scientific attitude, while the test sheet was used to determined the learning outcomes. The average score result for data analysis of teacher activity observation in first cycle was 24 (good), while in second cycle was 28 (good). The average score result for data analysis of scientific attitude observation in first cycle was 17,71 (enough), while in second cycle was 20,74 (good). The result of cognitive learning outcomes in first cycle was $66,66 \%$, while in second cycle was $84,85 \%$. The result of affective learning outcomes in first cycle was $69,69 \%$, while in second cycle was $100 \%$. The result of psychomotor learning outcomes in first cycle was $81,81 \%$, while in second cycle was $100 \%$. It was concluded that the problem based learning model can improve the scientific attitude and learning outcomes of the students of in class VIIB SMPN 11 Kota Bengkulu.
\end{abstract}

Keywords: Problem Based Learning, Scientific Attitudes 


\section{PENDAHULUAN}

Dalam rangka menerapkan pendidikan yang bermutu, pemerintah telah menetapkan kurikulum tahun 2013 untuk diterapkan pada sekolah atau madrasah. Tujuannya yaitu untuk mempersiapkan sumber daya manusia yang memiliki kemampuan hidup sebagai pribadi yang beriman, produktif, kreatif, dan inovatif melalui penguatan sikap, keterampilan, dan pengetahuan yang terintegritas. Hal ini dikarenakan proses pembelajaran pada kurikulum 2013 mencakup tiga aspek yaitu pengetahuan, sikap dan keterampilan. Aspek inilah yang dikembangkan dalam proses pembelajaran yang dimuat dalam standar kompetensi lulusan untuk mencapai tujuan pembelajaran sesuai dengan kurikulum 2013.

Salah satu mata pelajaran yang menjadi elemen penting dalam suatu kurikulum sekolah atau madrasah adalah ilmu pengetahuan alam. Pada pelajaran IPA tidak hanya melihat hasil belajar yang diperoleh siswa tetapi sikap ilmiah merupakan suatu yang harus diutamakan. Karena hasil belajar dan sikap ilmiah merupakan aspek penting didalam proses pembelajaran IPA (Nova, Sudiana, Widiana: 2013)

Menurut Trianto (2014) bahwa IPA memiliki nilai-nilai yang dapat ditanamkan pada pembelajaran IPA disekolah salah satunya yaitu memiliki sikap ilmiah yang di perlukan dalam memecahkan masalah baik dalam kaitannya dengan pelajaran sains maupun kehidupan. Untuk mencapai tujuan mata pelajaran IPA, salah satu faktor penting adalah sikap ilmiah siswa.

Proses pembelajaran IPA dalam kurikulum 2013 lebih mendorong dan melibatkan siswa agar lebih aktif dalam kegiatan pembelajaran agar tercapainya tujuan pembelajaran yang mencakup aspek pengetahuan, sikap, dan keterampilan. Namun yang terjadi di lapangan adalah pembelajaran IPA hanya sebatas transfer ilmu sang guru terhadap siswa dan masih berpusat pada guru. Siswa kurang aktif dan berminat dalam pembelajaran di kelas. Akibatnya pada kegiatan pem-belajaran di kelas, sikap ilmiah yang dimiliki oleh siswa kurang terlihat dan teramati dalam proses pembelajaran dan hasil belajar siswa belum mencapai ketuntasan belajar.

Berdasarkan hasil diskusi dan observasi peneliti dengan guru biologi di SMPN 11 Kota Bengkulu, ada beberapa masalah yang ditemui dalam proses pembelajaran, yaitu : 1) Hasil belajar siswa di kelas VII yang dilihat dari nilai ulangan harian memiliki ketuntasan belajar klasikal sebesar $42 \%$. Hanya 17 orng siswa dari 33 orang yang mencapai nilai KKM yaitu 75 . 2) Pada saat pembelajaran dikelas, aktivitas siswa yang berhubungan dengan penumbuhan sikap ilmiah kurang optimal. Hal tersebut dapat dilihat dari proses pembelajaran dikelas dimana beberapa siswa kurang aktif dan pembelajaran masih berpusat pada guru.

Guru perlu menerapkan pembelajaran yang dapat mengembangkan sikap ilmiah siswa yaitu dengan menggunakan pembelajaran yang memberi kesempatan kepada siswa terlibat aktif dalam proses pembelajaran melalui masalah-masalah yang bersifat nyata dan faktual. Salah satu model pembelajaran pada kurikulum 2013 yang mampu mengembangkan sikap ilmiah siswa dalam proses pembelajaran yaitu Problem Based Learning (PBL). Model pembelajaran Problem Based Learning adalah model pembelajaran yang berpusat pada siswa dan mampu menumbuhkan kemampuan berpikir, bekerja, dan sikap ilmiah. Problem Based 
Learning lebih menekankan pembelajaran pada pemecahan masalah dunia nyata oleh siswa untuk memperoleh pengetahuan dan konsep yang esensi pada materi pelajaran. (Rusman, 2014).

Dengan demikian proses pemecahan masalah yang dilakukan siswa dalam pembelajaran akan memberikan pemahaman yang lebih baik dan menjadi lebih bermakna. Sehingga apabila siswa telah dilibatkan dalam proses pembelajaran yang dilakukan guru maka diharapkan terciptanya sikap

\section{METODE}

Penelitian ini merupakan penelitian tindakan kelas dengan metode deskriptif yang pelaksanaannya terdiri dari dua siklus. Tiap siklus terdiri dari empat tahapan yaitu perencanaan, pelaksanaan, observasi dan refleksi. Subyek dalam penelitian ini adalah guru IPA dan seluruh siswa kelas VII ${ }_{B}$ SMPN 11 Kota Bengkulu tahun ajaran 2016/2017 yang berjumlah 33 orang yang terdiri dari 17 orang laki-laki dan 16 orang perempuan dengan penentuan subyek secara convenience sampling (ketersediaan). Penelitian ini dilaksanakan mulai tanggal 15 - 20 mei 2017. Teknik pengumpulan data pada penelitian ini yaitu observasi dan tes. Instrumen penelitian yang digunakan adalah lembar observasi dan lembar tes. Lembar observasi digunakan untuk mengamati sikap ilmiah siswa dan lembar tes untuk mengukur hasil belajar siswa.

Teknik analisis data yang digunakan yaitu secara deskriptif untuk mendeskripsikan proses pembelajaran menggunakan model Problem Based Learning yang dilakukan oleh guru, gambaran sikap ilmiah siswa, dan gambaran hasil belajar siswa. Data penilaian aktifitas guru, sikap ilmiah, dan hasil belajar kognitif siswa dianalisis ilmiah. Sehingga dapat disimpulkan pembelajaran menggunakan Problem Based Learning akan mendorong pembentukan sikap ilmiah pada diri siswa dan diharapkan mampu meningkatkan hasil belajar siswa. Berdasarkan hal tersebut peneliti bekerja sama dengan guru IPA untuk melakukan penelitian tindakan kelas (PTK) yang bertujuan untuk memperbaiki proses pembelajaran di kelas dengan judul penelitian yaitu Peningkatan Sikap IImiah Dan Hasil Belajar Siswa Dengan Model Problem Based Learning.

secara deskriptif dengan cara mencari rerata. Rumus rerata Setyosari (2015) :

$$
\bar{X}=\frac{\sum X}{N}
$$

$\Sigma X \quad=$ jumlah seluruh skor pengamatan

$n \quad=$ jumlah observer/pengamat

Kategori rerata dan skor aspek pembelajaran dikategorikan dalam kategori baik, cukup, dan kurang. Penentuan kategori skor setiap kategori menggunakan rumus menurut Sudijono (2012), yaitu:

Rentang kategori $=$

skor tertinggi-skor terendah

$$
\text { jumlah kategori }
$$

Untuk memperoleh keseluruhan persentase sikap ilmiah siswa digunakan rumus persentase. Rumus persentase kategori menurut Setyosari (2015), yaitu:

$\mathrm{P}=\frac{f}{N} \times 100 \%$

Keterangan:

$\mathrm{P} \quad=$ Angka Persentase

$\%=$ Persentase siswa kategori

Baik/Cukup/Kurang

$f \quad=$ Jumlah siswa untuk kategori

Baik/Cukup/Kurang

$\mathrm{N} \quad=$ Jumlah keseluruhan siswa 
Untuk data hasil belajar afektif, skor akhir dihitung menggunakan rumus rentang 1 sampai 4. Perhitungan skor akhir menggunakan rumus sebagai berikut (Zubaidah dkk, 2014):

Skor Akhir $=\frac{\text { Skor yang diperoleh }}{\text { Skor maksimal }} \times 4$

Peserta didik memperoleh nilai :

Sangat baik : apabila memperoleh skor $3,20-4,00$

Baik : apabila memperoleh skor

$2,80-3,19$

Cukup : apabila memperoleh skor $2,40-2,79$
Kurang : apabila memperoleh skor < 2,40

Data hasil belajar psikomotor dihitung menggunakan rumus sebagai berikut (Panduan Penilaian Untuk SMP Tahun 2015):

Nilai $=\frac{\text { Jumlah Skor yang diperoleh }}{\text { Jumlah skor maksimal }} \times 100$

Untuk mengetahui persentase ketuntasan belajar klasikal menggunakan rumus sebagai berikut (Zubaidah dkk, 2014) :

$\mathrm{P}=\frac{\sum \text { Siswa yang tuntas belajar }}{\sum \text { siswa }} \times 100 \%$

Keterangan :

$\mathrm{P}=$ persentase ketuntasan belajar klasikal 


\section{HASIL DAN PEMBAHASAN}

Berdasarkan penelitian yang telah dilaksanakan dengan menerapkan model Problem Based Learning untuk meningkatkan sikap ilmiah dan hasil belajar siswa kelas $\mathrm{VII}_{\mathrm{B}}$ SMPN 11 Kota
Bengkulu pada materi Pencemaran Lingkungan dengan sub materi "Pencemaran Udara" pada siklus I dan "Pencemaran Air" pada siklus II, dapat dilihat pada Tabel 1.

Tabel 1. Data hasil analisis aktivitas mengajar guru dengan mnerapkan model Problem Based Learning pada siklus I dan siklus II

\begin{tabular}{cccccc}
\hline Siklus & Pengamat & Skor & Total skor & Rata-rata & kategori \\
\hline \multirow{2}{*}{1} & I & 24 & 48 & 24 & Baik \\
& II & 24 & & & \\
2 & I & 28 & 56 & 28 & Baik \\
\hline
\end{tabular}

Berdasarkan Tabel 1, aktivitas mengajar guru dengan me-nerapkan model Problem Based Learning secara keseluruhan terjadi peningkatan kegiatan pembelajaran dari siklus I ke siklus II dengan perolehan rata-rata pada siklus I 24 berkategori baik dan di siklus II dengan perolehan rata-rata 28 berkategori baik. Peningkatan kegiatan pembelajaran pada siklus II ini seiring dengan dilakukannya perbaikan setiap tahapan model Problem Based Learning dalam pembelajaran pada siklus I dan siklus II. Hal ini sesuai dengan pendapat Arikunto (2013) penelitian tindakan kelas adalah penelitian tindakan yang dilakukan oleh guru dengan tujuan memperbaiki mutu praktik pembelajaran di kelas, yang berfokus pada proses belajar mengajar yang terjadi di kelas sehingga dapat dimanfaatkan sebagai alat untuk pengembangan keahlian mengajar, memperbaiki praktek-praktek pembelajaran menjadi lebih efektif sehingga kualitas pembelajaran menjadi lebih baik dari kegiatan pembelajaran sebelumnya.

Pada siklus I tahap orientasi siswa pada masalah, tahap mengorganisasikan siswa untuk belajar dan tahap mengembangkan dan menyajikan hasil karya dinilai cukup oleh kedua observer. Sedangkan pada tahap menganalisis dan mengevaluasi proses pemecahan masalah dinilai kurang oleh kedua observer. Pada siklus II tahapan-tahapan model Problem Based Learning yang dilaksanakan dalam kegiatan pembelajaran sudah dinilai baik semua oleh observer, hal ini berarti terjadi peningkatan kegiatan pembelajaran dari siklus I ke siklus II. Perbaikan tahapan model Problem Based Learning yang dinilai kurang dan cukup oleh observer, dilakukan untuk meningkatkan kegiatan pembelajaran serta meningkatkan sikap ilmiah dan hasil belajar siswa sesuai dengan pendapat Rohman (2013) bahwa dalam penerapan PBL mampu mendorong kerjasama kelompok dalam menyelesaikan masalah, mendorong siswa dalam melakukan pengamatan dan penyelidikan yang memungkinkan untuk mereka memahami dan menjelaskan fenomena masalah dunia nyata, selain itu dengan keterlibatan tiga ranah (afektif, psikomotorik, dan kognitif) seimbang maka pemahaman konsep terhadap materi itu akan lebih lama diingat siswa sebab mereka sendiri yang membangun pengetahuan tersebut. 
Ada 5 dimensi sikap ilmiah yang dipilih untuk diamati dalam penelitian yaitu sikap ingin tahu, sikap respek terhadap data, sikap berpikir kritis, sikap peka terhadap lingkungan sekitar dan sikap bekerja sama. Data mengenai sikap ilmiah siswa dapat dilohat pada Tabel 2.

Tabel 2. Data hasil analisis sikap ilmiah siswa pada siklus I dan siklus II

\begin{tabular}{cccccc}
\hline \multirow{2}{*}{ Siklus } & \multicolumn{2}{c}{ Sikap ilmiah siswa } & \multicolumn{3}{c}{ \% kategori sikap ilmiah siswa } \\
\cline { 2 - 6 } & Rerata skor & kategori & Baik & Cukup & Kurang \\
\hline I & 17,71 & Cukup & 54,55 & 45,45 & 0 \\
II & 20,74 & Baik & 90,9 & 9,1 & 0 \\
\hline
\end{tabular}

Berdasarkan Tabel 2, pada siklus I kelima dimensi sikap ilmiah dalam kategori cukup dari penilaian observer dalam lembar observasi. Sedangkan pada siklus II kelima dimensi sikap ilmiah siswa dari lembar observasi meningkat menjadi kategori baik. Pada siklus I secara keseluruhan sikap ilmiah siswa termasuk kedalam kategori cukup. Dimana dimensi sikap ilmiah seperti rasa ingin tahu, respek terhadap data, berpikiri kritis, dan kerjasama masih berkategori cukup. Sedangkan Dimensi sikap ilmiah peduli lingkungan telah berkategori baik. Dari data yang diperoleh menunjukkan bahwa masih kurangnya sikap ilmiah siswa dalam proses pembelajaran sehingga menurunnya kualitas pembelajaran dikelas. Menurut Nova, Sudiana, Widiana (2013) berpendapat bahwa sikap antusias siswa dalam pembelajaran dapat dilihat dari perhatian siswa terhadap proses pembelajaran yang berlangsung, keinginan siswa untuk belajar serta ketekunannya dalam belajar.

Pada dimensi sikap rasa ingin tahu dinilai cukup pada siklus I karena dalam proses pembelajaran siswa aktif mencari informasi dan jawaban LKS/LDS melalui buku saja tanpa adanya diskusi bersama teman kelompok. Padahal siswa dituntut untuk bekerjasama dalam kelompok dalam memecahkan masalah atau menjawab pertanya yang ada pada
LKS/LDS. Padahal menurut Melani, dkk (2012) bahwa dengan diskusi kelompok siswa akan lebih mengingat apa yang didiskusikan daripada menerima penjelasan dari guru. Selain itu diskusi juga dapat meningkatkan pemahaman dan pengetahuan serta ketajaman berpikir siswa dengan belajar bersama.

Pada siklus II terjadi peningkatan karena peneliti membimbing siswa dalam memusatkan perhatian pada objek yang disajikan dan membimbing siswa dalam menanggapinya. Peneliti juga membimbing siswa dalam kegiatan percobaan yang dilakukan serta membimbing siswa menjawab pertanyaan pada LKS/LDS berdasarkan percobaan yang dilakukan sehingga muncul sikap ingin tahu siswa dimana pada siklus II ini siswa sudah banyak yang bertanya ataupun menanggapi mengenai percobaan dan materi yang diajarka sehingga dinilai oleh kedua observer dengan kategori baik.

Pada dimensi respek terhadap data/fakta pada siklus I memiliki kategori cukup Pada dimensi ini siswa mengumpulkan data/informasi hanya berdasarkan pengamatan saja. Sehingga kurangnya diskusi kelompok siswa dan data/informasi yang dikumpulkan hanya sedikit dan tidak dijabarkan. Ini terjadi karena siswa asik bercerita sesama teman kelompok tanpa mendiskusikan data/informasi yang harus mereka diskusikan untuk men-jawab pertanyaan 
pada LDS/LKS. Padahal menurut Melani, dkk (2012) bahwa dengan diskusi kelompok siswa akan lebih mengingat apa yang didiskusikan mereka daripada menerima penjelasan dari guru. Selain itu diskusi juga dapat meningkatkan pemahaman, penge-tahuan dan ketajaman berpikir siswa. Pada siklus II terjadi peningkatan dari kategori menjadi kategori baik yang dinilai oleh kedua pengamat. Hal ini menunjukkan adanya progres ataupun kemajuan sikap ilmiah siswa sebagai respon siswa terhadap pembelajaran.

Pada dimensi berfikir kritis di siklus I tersebut yang dinilai kurang oleh kedua observer. Data yang diperoleh sesuai dengan kenyataan pada saat proses pembelajaran. Dimana saat pembelajaran terutama pada saat diskusi, siswa masih terlihat belum menunjukkan sikap berpikir kritis. Siswa hanya menerima saja dari jawaban yang disampaikan dan masih ada siswa yang mengabaikan data pengamatan, yaitu tidak mencatat semua data yang sudah diamati. Seharusnya siswa dapat menunjukkan sikap ilmiah terkait kegiatan pemecahan masalah terhadap masalah yang telah diberikan guru. Berpikir kritis merupakan suatu tingkatan berfikir tinggi. Seperti yang dikemukakan oleh Melani, dkk (2012) bahwa proses berpikir berkaitan erat dengan apa yang terjadi di dalam otak manusia, berpikir berkaitan dengan fakta-fakta yang ada dalam dunia, berpikir mungkin bisa divisualisasikan, dan berpikir (manakala diekspresikan) bisa diobservasi dan dikomunikasikan.

Pada siklus II terjadi peningkatan sehingga memperoleh kategor cukup walaupun masih ada siswa yang belum berpikir kritis dalam memecahkan masalah. Pada proses pembelajaran siswa belum menunjukkan sikap berpikir kritis karena belum mengikuti langkah- langkah dalam berpikir kritis. Beberapa langkah berpikir kritis menurut pendapat Ennis (1995) dalam Nova, Sudiana, Widiana (2013), yaitu: dalam berpikir kritis hendaknya fokus, memiliki alasan, mengambil kesimpulan, membaca situasi, melihat kejelasan dan pemeriksaan secara keseluruhan. Jika ke-seluruhan unsur ini tidak di-pertimbangkan secara matang maka siswa tidak dapat membuat keputusan/jawaban yang tepat serta munculnya sikap berpikir siswa dalam proses pembelajaran.

Pada dimensi kerjasama, pada siklus I dinilai dengan kategori cukup dan pada siklus II dinilai dengan kategori baik oleh kedua observer. Siswa terlihat kompak dalam mengerjakan dan berdiskusi dengan teman kelompoknya. Mereka bersama-sama mencari jawaban LDS/LKS yang dibagikan dan terlihat pembagian tugas yang terorganisasi dengan baik dimana satu siswa bertugas mencatat hasil diskusi sedangkan siswa lain berdiskusi bersama dan mencari jawaban serta mengaitkannya pada buku pelajaran. Hal ini sejalan dengan pendapat Melani, dkk (2012) bahwa kerjasama merupakan proses beregu (berkelompok) yang anggota-anggotanya mendukung dan saling mengandalkan untuk mencapai suatu hasil mufakat. Aspek-aspek dalam kerjasama kelompok meliputi komunikasi, koordinasi, dan saling tukar informasi agar dalam pengerjaan tugas kelompok siswa tetap kompak dan saling mendukung.

Pada dimensi Dimensi terakhir yaitu sikap peduli lingkungan dengan indikator menjaga kebersihan kelas. Pada indikator ini memperoleh kategori baik pada siklus I dan siklus II yang dinilai oleh kedua observer. Hal ini sesuai karena pada saat dikelas dan pembelajaran berlangsung terlihat kelas tetap bersih dan rapi karena siswa tersebut terbiasa menjaga kebersihan kelasnya selama 
belajar di kelas. Namun ada beberapa siswa yang nakal dan tidak mau diajak bekerjasama dalam menjaga kebersihan kelas. untuk data hasil belajar siswa dapat dilihat pada Tabel 3.

Tabel 3. Data hasil analisis hasil belajar siswa pada siklus I dan siklus II

\begin{tabular}{ccc}
\hline Siklus & Hasil belajar & Persentase ketuntasan klasikal \\
\hline & Kognitif & $66,66 \%$ \\
I & Afektif & $69,69 \%$ \\
& Psikomotor & $81,81 \%$ \\
\multirow{2}{*}{ II } & Kognitif & $84,85 \%$ \\
& Afektif & $100 \%$ \\
& Psikomotor & $100 \%$ \\
\hline
\end{tabular}

Berdasarkan Tabel 3, dapat dilihat bahwa secara keseluruhan hasil belajar afektif pada siklus I dinilai Baik dengan persentase ketuntasan kalsikal-nya yaitu sebesar $69,69 \%$ namun belum mencapai ketuntasan klasikal yang ditetapkan oleh pihak sekolah dan hasil belajar psikomotor pada siklus I dinilai Tuntas dengan persentase ketuntasan kalsikalnya yaitu sebesar $81,81 \%$. Hal ini telah menunjukkan bahwa siswa terlibat aktif pada kegiatan pembelajaran, sedangkan hasil belajar kognitif belum mencapai ketuntasan belajar klasikal yaitu hanya $66,66 \%$ dari jumlah keseluruhan siswa. Dapat disimpulkan bahwa pembelajaran pada siklus I belum mencapai ketuntasan klasikal, sehingga perlu perbaikan pada saat siklus II dengan harapan siswa dapat mencapai ketuntasan belajar klasikal atau seluruhnya.

Pada siklus II, terjadi peningkatan persentase ketuntasan klasikal siswa baik hasil belajar dari ranah kognitif, afektif, maupun psikomotor. Peningkatan proses pembelajaran yang terjadi sejalan dengan peningkatan hasil belajar yang capai oleh siswa. Menurut Green dalam Idrus (2009) Penilaian hasil belajar idealnya dapat mengungkap semua aspek domain pembelajaran, yaitu aspek pengetahuan, sikap dan keterampilan. Sebab siswa yang memiliki kemampuan kognitif baik saat diuji dengan tes belum tentu ia dapat menerapkan dengan baik pengetahuannya dalam mengatasi permasalahan kehidupan.

Peningkatan persentase jumlah ketuntasan klasikal dari siklus I ke siklus II menunjukkan bahwa model pembelajaran Problem Based Leraning dapat meningkatkan hasil belajar kognitif, afektif dan psikomotor siswa. Hal ini sesuai dengan penelitian sebelumnya yang dilakukan Ramdani (2016) bahwa model pembelajaran Problem Based Leraning dapat meningkatkan hasil belajar IPA siswa pada kompetensi pengetahua. Ini artinya kemampuan siswa dalam kompetensi pengetahuan sudah meningkat dan telah tuntas untuk mencapai tujuan pembelajaran yang telah ditetapkan. Dimana yang dikatakan tuntas menurut Trianto (2014) merupakan arah optimalisasi hasil pembelajaran peserta didik. Arah optimalisasi ini menunjukkan ketuntasan belajar peserta didik yang diperoleh berupa angka dan ketercapaian kompetensi siswa pada proses pembelajaran.

Peningkatan persentase jumlah ketuntasan belajar siswa pada ranah afektif menunjukkan bahwa model pembelajaran Problem Based Learning dapat meningkatkan hasil belajar kompetensi sikap. Hasil ini diperkuat oleh Ibrahim, dkk dalam Trianto (2014) bahwa dengan menggunakan model Problemn 
Based Learning dapat mengembangkan kualitas diri siswa terutama aspek afektif. Dimana telah dikatakan sebelumnya, bahwa pada proses pembelajaran yang dilakukan siswa dilatih untuk bekerja sama dan saling menghormati pendapat di dalam anggota kelompok. Selain itu menurut Majid (2011) dalam kegiatan pembelajaran, penilaian terhadap sikap selain bermanfaat untuk mengetahui faktor-faktor psikologis yang mempengaruhi pembelajaran, berguna juga sebagai feedback pengembangan pembelajaran.

Selain kompetensi sikap diatas, dilihat juga kompetensi keterampilan. Peningkatan ketuntasan belajar siswa ranah psikomotor tersebut mem-buktikan terjadi peningkatan hasil belajar pada kompetensi keterampilan sebesar 18,19\%. dengan menerapkan model Problem Based Learning. Peran PBL dalam membantu hasil belajar psikomotor diungkapkan Savery \& Dufy (2001) dalam Nurtanto (2016) menjelaskan bahwa hubungan antara teori dan praktik bahwa dalam lingkungan PBL siswa terlibat aktif bekerja sesuai dengan tugas dan kegiatan otentik sesuai lingkungan dimana mereka akan menggunakannya atau bekerja. Fokusnya adalah siswa mengkonstruk pengetahuan mereka sendiri dalam konteks yang mirip dengan konteks dimana akan me-nerapkan pengetahuan itu. Sehingga, PBL mengkonstruksi pengetahuan dan mengaplikasikannya dalam keteram-pilan.

\section{PENUTUP}

\section{Simpulan}

Berdasarkan Penelitian Tindakan Kelas (PTK) yang dilakukan Kelas VIIB SMPN 11 Kota Bengkulu dengan menerapkan model Problem Based Learning pada materi Pencemaran Lingkungan, dapat disimpulkan sebagai berikut:
1. Perbaikan pembelajaran dengan menerapkan model Problem Based Learning pada Materi Pencemaran Lingkungan termasuk dalam kategori baik dan meningkat dari siklus I ke siklus II. Pada siklus I diperoleh ratarata 24 dengan kategori baik dan pada siklus II diperoleh rata-rata 28 dengan kategori baik diantaranya pada tahap guru mengorientasi siswa pada masalah dan tahap mengembangkan dan menyajikan hasil karya.

2. Perbaikan pembelajaran dengan menerapkan model Problem Based Learning pada materi Pencemaran Lingkungan dapat meningkatkan sikap ilmiah siswa Kelas VIIB SMPN 11 Kota Bengkulu dari siklus I ke siklus II

3. Perbaikan pembelajaran dengan menerapkan model Problem Based Learning pada materi Pencemaran Lingkungan dapat meningkatkan hasil belajar siswa Kelas VIIB SMPN 11 Kota Bengkulu dari siklus I ke siklus II

\section{Saran}

Berdasarkan penelitian yang telah dilakukan, beberapa saran yang dapat dianjurkan yaitu :

1. Diharapkan kepada guru mata pelajaran IPA Kelas VIIB SMPN 11 Kota Bengkulu dapat menggunakan model Problem Based Learning sebagai salah satu alternatif dalam pembelajaran untuk diterapkan pada pembelajaran IPA sebagai salah satu upaya meningkatkan sikap ilmiah dan hasil belajar siswa dengan menggunakan tahapan pembelajaran yang tepat.

2. Bagi peneliti selanjutnya dapat melanjutkan hasil penelitian ini ke 
penelitian selanjutnya dengan jenis penelitian berbeda ataupun serupa dengan subyek berbeda serta model yang berbeda agar lebih dapat mengembangkan sikap ilmiah pada diri siswa serta hasil belajar siswa.

\section{DAFTAR PUSTAKA}

Anwar, Herson. 2009. Penilaian Sikap Ilmiah Dalam Pembelajaran Sains. Jurnal Pelangi IImu Volume 2 No. 5, Mei 2011

Arikunto, Suharsimi. 2013a. Dasar - Dasar Evaluasi Pendidikan. Jakarta: PT Bumi Aksara.

Badan Standar Nasional Pendidikan. 2006. Standar Isi Untuk Satuan Pendidikan Dasar dan Menengah: Standar Kompetensi dan Kompetensi Dasar SMP/MTs. Jakarta: BSNP

Idrus, Ali. 2009. Manajemen Pendidikan Global. Jakarta: Gaung Persada

Majid, Abdul. 2011. Perencanaan Pembelajaran. Bandung: PT Remaja Rosdakarya

Melani, Riyan., Harlita. dan Sugiharto, Bowo. 2012. Pengaruh Metode Guided Discovery Learning Terhadap Sikap IImiah Dan Hasil Belajar Kognitif Biologi Siswa SMA Negeri 7 Surakarta Tahun Pelajaran 2011/2012. Pendidikan Biologi Volume 4, Nomor 1.

Nova, Sudiana, Widiana. 2013. Pengaruh Model Pembelajaran SAVI Berorientasi pada Keterampilan Proses Sains Terhadap Hasil Belajar IPA siswa kelas $V$ SD gugus $V$
Kecamatan Tejakula. Jurusan PGSD, FKIP Universitas Pendidikan Ganesha, Singaraja, Indonesia

Nurtanto, Muhammad. 2016. Peningkatan Aktivitas Dan Hasil Belajar Psikomotor Dengan Metode Problem Based Learni. Jurnal Pendidikan Teknik Mesin Universitas Sultan Ageng Tirtayasa. http://ejournal.ikippgrimadiun.ac.id/index. php/JP-

LPPM/article/view/425/396

diakses pada tanggal 18 juni 2017)

Ramdani, Bopy. 2016. Peningkatan Aktivitas Dan Hasil Belajar Siswa Kelas X IPA.5 Madrasah Aliyah Negeri (MAN) 1 Bengkulu Pada Konsep Jamur (Fungi) Dengan Penerapan Model Pembelajaran Berbasis Masalah Melalui Pendekatan Kontekstual. Skripsi tidak diterbitkan. Program Studi Pendidikan Biologi. FKIP Universitas Bengkulu

Rohman, Arif. 2013. Memahami Pendidikan dan Ilmu Pendidikan.Yogyakarta : LaksBang Mediatama Yogyakarta

Rusman, $2014 . \quad$ Model-Model Pembelajaran. Jakarta: Rajawali Press

Setyosari, P. 2015. Metode Penelitian Pendidikan dan Pengembangan. Jakarta : Kencana.

Sudijono, Anas. 2012. Pengantar Statistik Pendidikan. Jakarta: Rajawali Pers.

Trianto. 2014. Model Pembelajaran Terpadu. Jakarta: PT Bumi Aksara.

Zubaidah, Siti dkk. 2014. Buku guru Ilmu Pengetahuan Alam. Jakarta: Kementerian Pendidikan dan Kebudayaan. 